\begin{tabular}{|c|l|}
\hline Title & Spatial variation in the parasitic isopod load of the Japanese halfbeak in western Japan \\
\hline Author(s) & Kawanishi, R.; Sogabe, A.; Nishimoto, R.; Hata, H. \\
\hline Citation & $\begin{array}{l}\text { Diseases of aquatic organisms, 122(1), 13-19 } \\
\text { https://doi.org/L0.3354/dao03064 }\end{array}$ \\
\hline Issue Date & 2016-11-22 \\
\hline Doc URL & http://hdl.handle.net/2115/64877 \\
\hline Rights(URL) & https://reativecommons.org/icenses/oy/3.0/ \\
\hline Type & article \\
\hline File Information & d122p013.pdf \\
\hline
\end{tabular}

Instructions for use 


\title{
Spatial variation in the parasitic isopod load of the Japanese halfbeak in western Japan
}

\author{
R. Kawanishi ${ }^{1, *}$, A. Sogabe ${ }^{2}$, R. Nishimoto ${ }^{3}$, H. Hata ${ }^{4}$ \\ ${ }^{1}$ Faculty of Environmental Earth Science, Hokkaido University, Sapporo, Japan \\ ${ }^{2}$ Faculty of Agriculture and Life Science, Hirosaki University, Hirosaki, Japan \\ ${ }^{3}$ Faculty of Science, Ehime University, Matsuyama, Japan \\ ${ }^{4}$ Graduate School of Science and Engineering, Ehime University, Matsuyama, Japan
}

\begin{abstract}
Cymothoid isopods (family Cymothoidae) are commonly found parasitizing diverse fishes, including commercial species. However, the effects of these parasites on host body condition are still poorly known. Here we investigated the spatial variation of the effects of parasite infection on host body condition, using the parasitic load of the cymothoid Mothocya parvostis on the Japanese halfbeak Hyporhamphus sajori at 4 sampling sites in western Japan. M. parvostis prevalence at each site (41.6-74.4\%) was higher than that known for other fish host-cymothoid systems (usually less than $30 \%$ ). The number of isopods in infected hosts, the reproductive status of female isopods (i.e. ovigerous/non-ovigerous), and the body size of female and male isopods relative to the size of their hosts were not significantly different among sites. However, at the site where human activity was most intense, $M$. parvostis infection had a significantly negative effect on host body condition. These results suggest that the effect of cymothoid infection on host body condition might be benign under natural conditions but becomes detrimental in habitats that are unsuitable for the host, such as highly human-impacted areas.
\end{abstract}

KEY WORDS: Cymothoidae $\cdot$ Gill parasite $\cdot$ Isopod $\cdot$ Mothocya parvostis $\cdot$ Hyporhamphus sajori $\cdot$ Host body condition $\cdot$ Habitat heterogeneity

\section{INTRODUCTION}

The Cymothoidae, one of the largest families of parasitic isopods, comprise more than 380 species (Poore \& Bruce 2012, Smit et al. 2014). They parasitize a diverse array of marine, brackish, and freshwater fishes worldwide, including commercially important species (Brusca 1981, Bruce 1986, Thatcher 2006). Host specificity and host range vary among cymothoid species, ranging from 1 to $>10$ hosts (e.g. Yamauchi \& Nagasawa 2012, Martin et al. 2015). The isopods are usually attached to a particular site on the host, which is typically consistent within species, i.e. host body surface, gills, mouth, or body cavity (Bello et al. 1997, Fogelman et al. 2009, Bottari et al. 2013), where they feed on blood, mucus, and/or tissues (Adlard \& Lester 1995, Horton \& Okamura 2003). Free-swimming larvae (mancae), immotile adults, and protandrous hermaphroditism characterize the cymothoid life cycle. Mancae released from the maternal marsupium seek and attach to suitable hosts (Adlard \& Lester 1995, Fogelman \& Grutter 2008), on which they molt several times before losing their swimming setae and becoming males. Apparently, when no female cymothoid is present on the host individual, one of the males transforms into an adult female (Adlard \& Lester 1995). Cymothoids lose their swimming ability during development, and at least female cymothoids become immotile, although the timing at which this occurs is unclear (Adlard \& Lester 1995). 
Infection with cymothoid isopods can cause skin lesions and anemia, and it can also increase the cost of swimming for the hosts (Horton \& Okamura 2003, Östlund-Nilsson et al. 2005, Binning et al. 2013). Nevertheless, many studies have found that cymothoid infection does not influence the growth and body condition of hosts (Colorni et al. 1997, Leonardos \& Trilles 2003, Carrassón \& Cribb 2014). In contrast, a few studies have found that cymothoid infection significantly deteriorates host condition (Gomiero et al. 2012, Sala-Bozano et al. 2012). Östlund-Nilsson et al. (2005) found no significant differences between the body condition of wild-caught cardinal fish Cheilodipterus quinquelineatus Cuvier, 1828 infected and uninfected with the cymothoid isopod Anilocra apogonae Bruce, 1987. However, when exposed to low food availability under experimental conditions, infected fish lost more weight than uninfected fish. This suggests that the negative effects of cymothoid infection on host fishes appear only when the habitat is unsuitable for the host (e.g. low food availability and high energy demand). Human activities such as coastal development and navigation have degraded the marine environment, with several degrees of intensity along the coast (Halpern et al. 2008), increasing the spatial variation in habitat suitability for marine organisms. Thus, the effect of cymothoid isopods on fish might also show spatial variation across host and parasite distributional ranges. This issue has received little attention in most fish-cymothoid systems studied, although Sala-Bozano et al. (2012) discussed possible spatial variation in cymothoid infection.

The Japanese halfbeak Hyporhamphus sajori (Temminck \& Schlegel, 1846) is a pelagic fish inhabiting the coastal waters of Japan, China, and the Korean Peninsula (Nakabo 2002), which is frequently parasitized in the gill cavity by cymothoid species of the genus Mothocya (M. parvostis Bruce, 1986 and M. sajori Bruce, 1986). Despite the commercial importance of $H$. sajori in these countries, its total population size has recently decreased (Tsuji \& Sadakata 2000). The aim of the present study was to determine the spatial variation in cymothoid prevalence and its effects on $H$. sajori body condition. For this purpose, Japanese halfbeak individuals were collected from 4 sites in western Japan, presenting different levels of human impact.

\section{MATERIALS AND METHODS}

\section{Study area}

Fish were sampled from 4 sites located in the Seto Inland Sea (Onomichi, Mitsuhama, and Ushimado) and in the Sea of Japan (Yoshimi), western Japan, from mid-autumn to early winter, in 2011 and 2012 (Table 1, Fig. 1). The Seto Inland Sea is a semienclosed coastal sea surrounded by 3 large islands

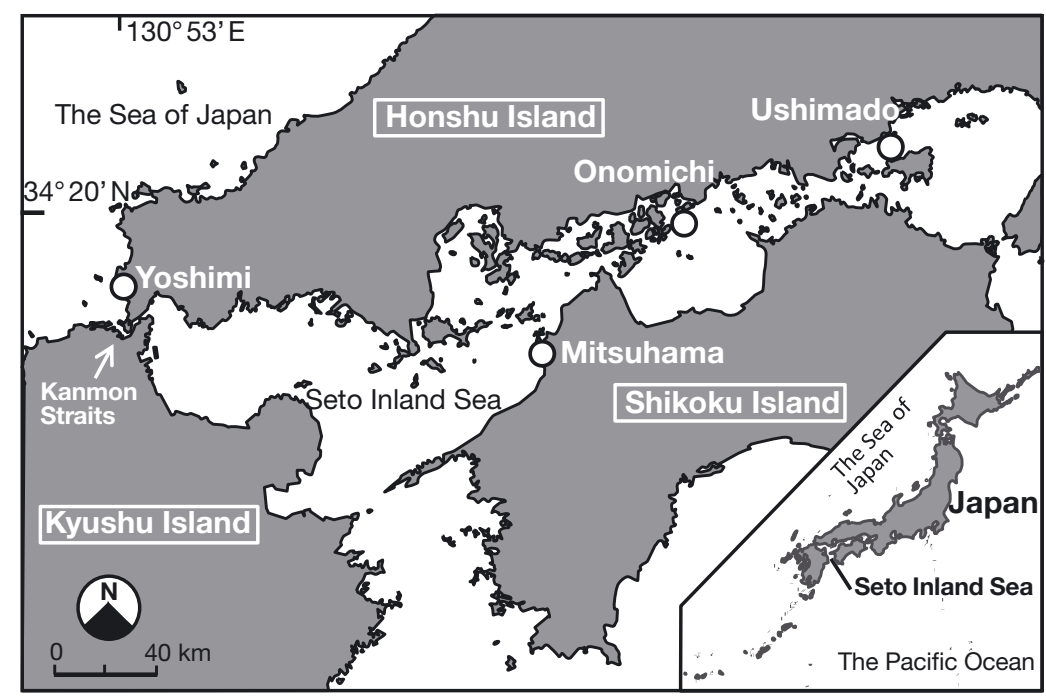

Fig. 1. Geographic location of fish sampling sites (open circles) in western Japan

Table 1. Information on the Japanese halfbeak Hyporhamphus sajori collected at the 4 sampling sites

\begin{tabular}{|c|c|c|c|c|c|c|}
\hline & \multirow[t]{2}{*}{$\begin{array}{l}\text { Sampling } \\
\text { site }\end{array}$} & \multirow[t]{2}{*}{ Date } & \multirow{2}{*}{$\begin{array}{c}\text { No. of fish } \\
\text { collected } \\
\text { (uninfected/infected) }\end{array}$} & \multirow{2}{*}{$\begin{array}{c}\text { Parasite } \\
\text { prevalence } \\
(\%)\end{array}$} & \multicolumn{2}{|c|}{$\begin{array}{l}\text { Standard length } \\
(\text { mean } \pm \mathrm{SD}, \mathrm{mm})\end{array}$} \\
\hline & & & & & Uninfected & Infected \\
\hline Onomichi & $\left(34^{\circ} 20^{\prime} \mathrm{N}, 133^{\circ} 13^{\prime} \mathrm{E}\right)$ & 17 November 2011 & $20(11 / 9)$ & 45.0 & $277.5 \pm 16.3$ & $262.3 \pm 19.9$ \\
\hline Yoshimi & $\left(34^{\circ} 04^{\prime} \mathrm{N}, 130^{\circ} 53^{\prime} \mathrm{E}\right)$ & 23 September 2012 & $21(7 / 14)$ & 66.7 & $161.9 \pm 8.8$ & $159.3 \pm 12.6$ \\
\hline Mitsuhama & $\left(33^{\circ} 51^{\prime} \mathrm{N}, 132^{\circ} 42^{\prime} \mathrm{E}\right)$ & 12 October 2012 & $77(45 / 32)$ & 41.6 & $166.0 \pm 10.7$ & $163.6 \pm 11.8$ \\
\hline Ushimado & $\left(34^{\circ} 36^{\prime} \mathrm{N}, 134^{\circ} 09^{\prime} \mathrm{E}\right)$ & 18 December 2012 & $43(11 / 32)$ & 74.4 & $201.1 \pm 23.4$ & $194.2 \pm 21.0$ \\
\hline
\end{tabular}


(Honshu, Shikoku, and Kyushu), with more than 3000 small islands. This inland sea is connected to the Pacific Ocean on the east and west sides of Shikoku Island, and to the Sea of Japan via the Kanmon Straits. These 4 sites were selected to encompass the diverse marine habitats within the study area, including those influenced by human activities. The offshore areas Onomichi and Ushimado contrast with the coastal Mitsuhama and Yoshimi, with Mitsuhama being located in a ferry and fishery port of an intermediate-sized provincial city, Matsuyama, and Yoshimi in a small fishery harbor in a rural town.

\section{Sampling and measurement of fish and their parasites}

Japanese halfbeak were obtained by fishing from the shore or from a boat, except at Onomichi, where they were purchased from a fish shop (Table 1). After removing cymothoids, all fish were wet weighed to the nearest $0.01 \mathrm{~g}$ and their standard length (SL) was measured to the nearest $0.1 \mathrm{~mm}$. The number of cymothoid individuals per fish and cymothoid total length (TL; nearest $0.01 \mathrm{~mm}$ ), wet weight (nearest $0.001 \mathrm{~g})$, and sex were recorded. Based on Bruce's (1986) identification keys, all cymothoid individuals collected were identified as Mothocya parvostis, although the TL of some females was slightly larger (up to $18.71 \mathrm{~mm}$ ) than that of M. parvostis ( $\leq 15 \mathrm{~mm}$ $\mathrm{TL})$, but smaller than that of $M$. sajori ( $\geq 20 \mathrm{~mm} \mathrm{TL})$, reported by Bruce (1986). Developmental stage (i.e. mancae or not) was determined based on the morphology of the seventh pereopod. Female M. parvostis were classified as non-ovigerous (individuals with no visible eggs, embryos, or mancae) or ovigerous. Because cymothoid isopods are syngenetic, when only 1 ovigerous female was found in a host, it was considered that the male cohabiting with this female was accidently lost during host sampling; in such cases, the number of individuals per fish was recorded as 2 (i.e. a female-male pair). The tiny mancae $(2-4 \mathrm{~mm} \mathrm{TL},<0.001 \mathrm{~g})$ found only on 6 fish individuals were removed from the analyses to avoid the accidental inclusion of mancae released from the female marsupium during the sampling process (Williams \& Williams 1985).

\section{Statistical analyses}

Differences in parasite prevalence, number of isopods per infected fish, and number of ovigerous/ non-ovigerous female cymothoids between the 4 sampling sites were tested using Fisher's exact test followed by Benjamini and Hochberg's correction for multiple comparisons.

To compare the effects of cymothoid infection on host body condition among the sampling sites, the concept of relative weight (Wege \& Anderson 1978) was applied. First, a linear logarithmic weight-length equation was developed using the uninfected fish individuals $\left(\log W=3.2274 \log S L-6.0268, \mathrm{R}^{2}=0.99\right.$, $\mathrm{p}<0.001$; Fig. 2A). The relative weight, $W_{\mathrm{r}}$, was then calculated for all fish according to:

$$
W_{\mathrm{r}}(\%)=\left(W / W_{\mathrm{e}}\right) \times 100
$$

where $W$ is the measured fish weight and $W_{\mathrm{e}}$ is the expected weight at a given body length (calculated from the weight-length equation).

Similarly, isopod body size in relation to host body size was calculated to determine the spatial variation of $M$. parvostis parasitic load. Linear logarithmic fish length-isopod length equations were developed separately for female and male isopods (female, $\log T L_{\text {isopod }}=0.7835 \log S L_{\text {fish }}-0.7027, \mathrm{R}^{2}=0.69, \mathrm{p}<$
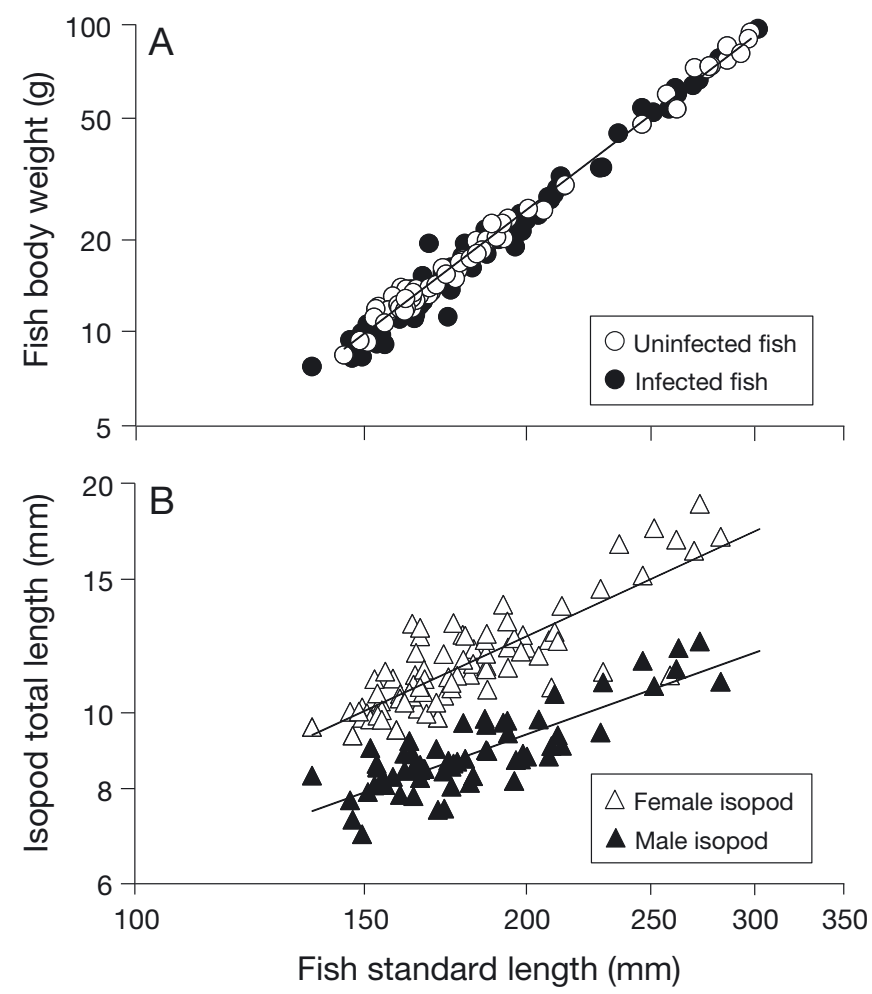

Fig. 2. (A) Relationship between Japanese halfbeak Hyporhamphus sajori standard length and body weight; the linear regression (line) is based only on uninfected fish. (B) Relationship between Japanese halfbeak standard length and Mothocya parvostis male and female total length. Both axes are logarithmic 
0.001; male, $\log T L_{\text {isopod }}=0.61 \log S L_{\text {fish }}-0.4314, R^{2}=$ $0.69, \mathrm{p}<0.001$; Fig. 2B). The relative body size of isopods, $B S_{\mathrm{r}}$, was then calculated following:

$$
B S_{\mathrm{r}}(\%)=\left(B S / B S_{\mathrm{e}}\right) \times 100
$$

where $B S$ is the measured isopod length and $B S_{\mathrm{e}}$ is the expected isopod length at a given host length (calculated from the fish length-isopod length equation).

To examine the effects of cymothoid infection on the host, host SL and $W_{\mathrm{r}}$ were analyzed using a 2way analysis of variance (ANOVA) considering sampling site and the number of isopods as the main factors. If the effects of cymothoid infection on the host varied spatially, such differences should be reflected in the interaction 'site $\times$ number of isopods.' When this interaction was significant, multiple comparisons were performed within each sampling site, using Tukey's honestly significant difference (HSD) test. Spatial variations in the relative body size of both female and male isopods among sites were also examined using a 1-way ANOVA, considering sampling site as the main factor.

Host sex was not included as a factor in all analyses, because the gonadal index of the Japanese halfbeak is extremely low and similar between males and females during the non-reproductive season (approximately July to March in the Seto Inland Sea; Kuniyuki \& Koide 1962, Yamamoto 2008), therefore having a negligible effect. Fish SL was log-transformed before analyses to improve normality. All statistical analyses were performed in R 3.1.2 (R Core Team 2014) and $G^{*}$ Power 3 (Faul et al. 2007).

\section{RESULTS}

Among the 161 Japanese halfbeak individuals collected from the 4 sites, 87 were parasitized by Mothocya parvostis (Table 1): 17 fish carried 1 isopod and 69 fish carried 2 isopods (including 5 fish with a single ovigerous female) in the gill cavities. Most $(82.3 \%)$ of the single isopods were non-ovigerous females, $11.8 \%$ were males, and $5.9 \%$ were mancae; among the paired isopods, $98.6 \%$ were a femalemale pair (including 5 single ovigerous females) and $1.4 \%$ was a male-male pair; only 1 fish was parasitized by 3 isopods ( 1 female and 2 males). Data on the fish parasitized by 3 isopods were pooled with that of fish parasitized by 2 isopods in the subsequent analyses. The highest parasite prevalence was found in Ushimado, followed by Yoshimi, Onomichi, and Mitsuhama, and ranged from 74.4 to $41.6 \%$ (Table 1). However, multiple comparisons showed that preva- lence was only significantly different between Ushimado and Mitsuhama $(p=0.004)$. Based on Fisher's exact test, the number of isopods in infected hosts and the ratio of ovigerous to non-ovigerous female isopods were not significantly different among sites $(p=0.22$ and $p=0.35$, respectively); the percentage of ovigerous females among all female isopods ranged from 28.6 to $51.6 \%$.

The log-transformed SL of host fish did not differ according to the number of isopods $\left(F_{2,149}=2.00\right.$, power $=0.44, \mathrm{p}=0.14$ ) but was different among sites $\left(F_{3,149}=244.79\right.$, power $\left.>0.99, \mathrm{p}<0.001\right)$ : fish length was significantly different between all pairs of sites (Tukey's HSD, p < 0.001; Table 1), except between Mitsuhama and Yoshimi $(p=0.43)$. There was no significant interaction between sites and the number of isopods on host SL $\left(F_{6,149}=1.51\right.$, power $=0.61, \mathrm{p}=$ $0.18)$. However, the effect of this interaction on host $W_{\mathrm{r}}$ was significant, indicating a spatial variation in the effect of cymothoid infection on fish condition (number of isopods, $F_{2,149}=11.88$, power $>0.99, \mathrm{p}<$ 0.001 ; site, $F_{3,149}=6.75$, power $=0.98, \mathrm{p}<0.001$; number of isopods $\times$ site, $F_{6,149}=3.20$, power $=0.94, \mathrm{p}=$ 0.006). Multiple comparisons at each site showed that fish body condition was only significantly affected by cymothoid infection in Mitsuhama (Fig. 3). At this site, the relative weight of infected fish was significantly lower than that of uninfected fish (Tukey's HSD, $\mathrm{p}<0.05$ ) but was similar between infected individuals with different parasite loads $(p=0.90)$. In infected fish, $W_{\mathrm{r}}$ and SL were significantly and positively correlated $(\mathrm{r}=0.22, \mathrm{p}=0.04$; Fig. $4 \mathrm{~A})$, but this

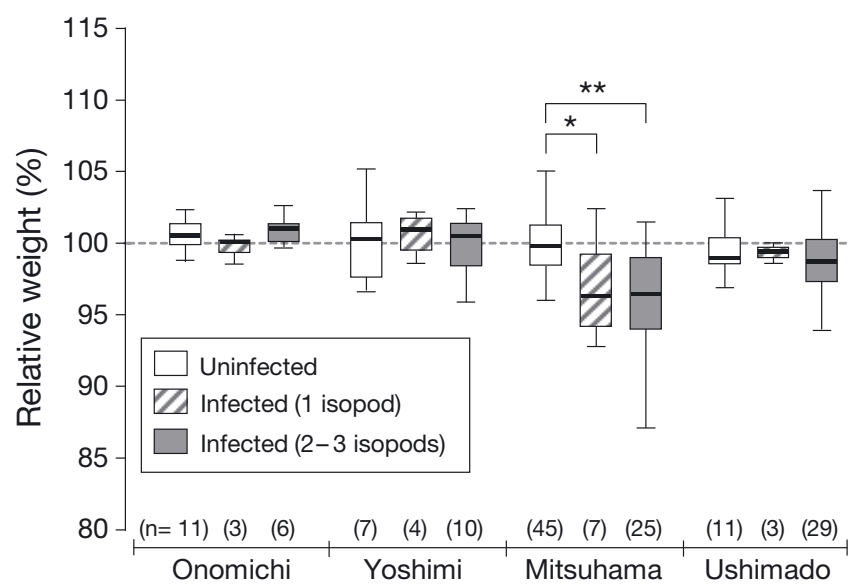

Fig. 3. Relative weight of Japanese halfbeak Hyporhamphus sajori infected with different loads of Mothocya parvostis at the 4 sampling sites. $\mathrm{n}$ : number of fish sampled within each category of parasite load. Horizontal lines within the boxes medians; boxes: interquartile ranges; whiskers: minimum and maximum values. Dashed line was drawn for reference. ${ }^{*} \mathrm{p}<0.05,{ }^{* *} \mathrm{p}<0.001$ 


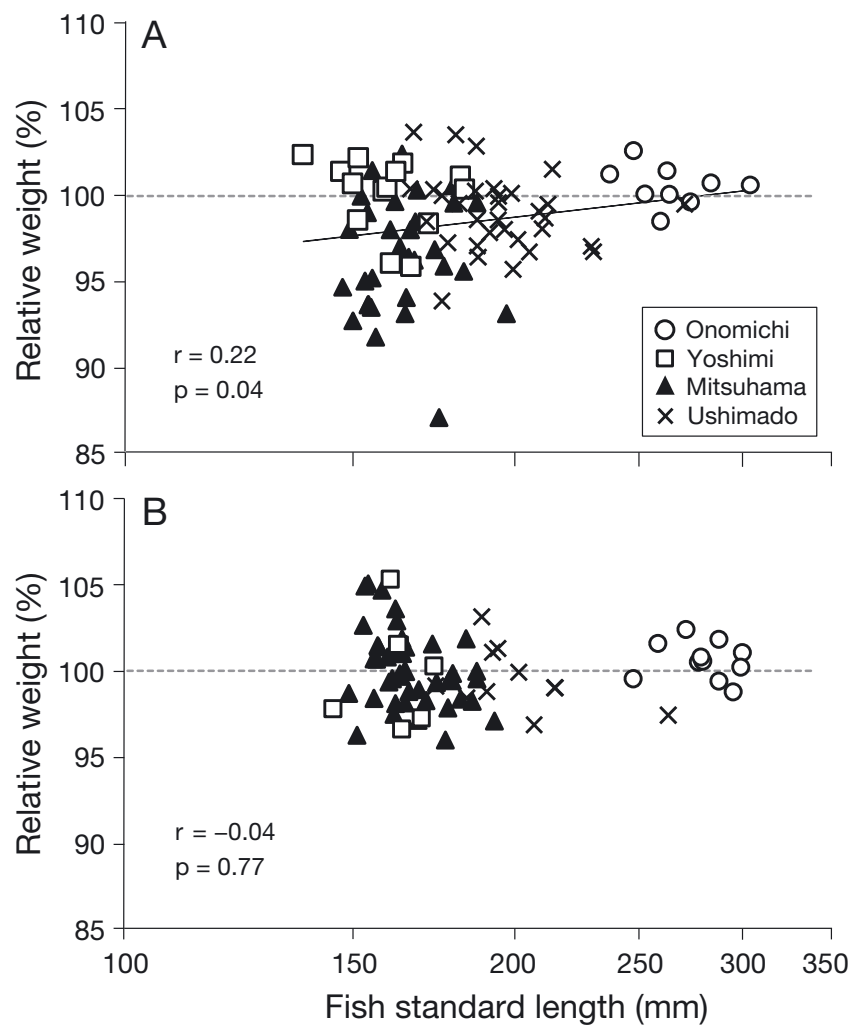

Fig. 4. Relationship between the standard length and relative weight of Japanese halfbeak Hyporhamphus sajori (A) infected with Mothocya parvostis and (B) uninfected. The $x$ axis is logarithmic. Dashed lines were drawn for reference

was not the case in uninfected fish $(\mathrm{r}=-0.04, \mathrm{p}=0.77$; Fig. 4B). However, when Mitsuhama data were removed, there was no correlation between the $W_{\mathrm{r}}$ and SL of infected fish $(r=-0.05, p=0.74)$, although SL range was maintained (Fig. 4A). The relative body size of both female and male isopods did not differ among sites (female, mean: 99.3-101.4\%, $F_{3,79}=0.94$, power $=0.26, \mathrm{p}=0.43$; male, mean: $99.0-101.9 \%$, $F_{3,63}=1.67$, power $=0.44, \mathrm{p}=0.18$ ).

\section{DISCUSSION}

The present study revealed that the effect of Mothocya parvostis infection on host body condition varied among sampling sites and was only negative in Mitsuhama, where infected fish showed lower relative weight than uninfected fish. However, this did not seem to result from spatial differences in the number of parasites infecting hosts, parasite reproductive stage (i.e. ovigerous/non-ovigerous), or parasite relative body size, as these were not consistent with the results obtained for host body condition. The relative weight of infected fish significantly de- creased with decreasing body size, and fish from Mitsuhama were relatively smaller than fish collected at other sites. These results apparently suggest a sizedependent vulnerability of Japanese halfbeak to cymothoid infection. However, when data from Mitsuhama were removed, there was no significant correlation between the relative weight and SL of infected fish $(\mathrm{r}=-0.05)$, although $\mathrm{SL}$ range was maintained. Thus, the relationships observed in Mitsuhama appear to be attributable to the unique characteristics of this site, rather than simply reflecting size-dependent vulnerability of the host.

Sala-Bozano et al. (2012) compared the effects of cymothoid infection on host growth and body condition between an area close to a marine protected area and an area of intense fishing pressure, and only found negative effects in the fishing area. This suggested that the energy loss caused by cymothoid infection could be readily compensated for in natural environments, by allocating extra time to feeding, but not in highly human-impacted environments, due to the increased energy demand to cope with the harsh environment and/or the limited energy intake resulting from low food availability (Östlund-Nilsson et al. 2005). In the present study, Mitsuhama was the most human-impacted area among the sampling sites. Although an evaluation of habitat quality was not conducted, human activities typically degrade fish habitat (e.g. by deteriorating water quality and reducing prey abundance). In addition, Mitsuhama is a strategic place for sea navigation. Navigation activities are known to negatively affect the abundance of certain fish species and alter their schooling behavior (Sandström et al. 2005, Sarà et al. 2007). Therefore, the Japanese halfbeak in Mitsuhama might be subjected to several stresses associated with human activities, resulting in a decrease in energy compensation against parasite infection.

On the other hand, $M$. parvostis infection had no significant effects on Japanese halfbeak body condition at the other 3 sites. Although the negative effects of parasites might be too small to be detected with the sample sizes used in this study, many authors have reported similar benign effects of cymothoid infection on host fishes (Colorni et al. 1997, Leonardos \& Trilles 2003, Carrassón \& Cribb 2014), which seems to be closely related to the life history characteristics of cymothoids. For mature cymothoid isopods, killing their host would impose a high cost, as they are unable to swim after maturation and hence cannot find a new host (Smit et al. 2014). In such host-parasite systems, parasites might have evolved to optimize the intensity of nutritional exploitation of 
their host to a degree that will not kill the host and allows the parasite to grow with the host (Jensen et al. 2006). Positive correlations between cymothoid and host body sizes have generally been found (Colorni et al. 1997, Leonardos \& Trilles 2003, Carrassón \& Cribb 2014), as was the case in our study. Taken together, current fish-cymothoid systems might have achieved equilibrium through the process of coevolution between parasites and hosts in their natural habitat. Serious effects of infection with native cymothoids on the growth and survival of farmed fish have provided support for this hypothesis (Sievers et al. 1996, Papapanagiotou \& Trilles 2001).

The prevalence of $M$. parvostis on Japanese halfbeak in the present study $(41.6-74.4 \%)$ was relatively high among known fish-cymothoid systems, where prevalence is typically less than $30 \%$, e.g. approximately $14 \%$ in Paracymothoa astyanaxi Lemos de Castro, 1955 parasitizing Astyanax intermedius Eigenmann, 1908 (Gomiero et al. 2012) and up to $28 \%$ in Anilocra nemipteri Bruce, 1987 parasitizing Scolopsis bilineata (Bloch, 1793) (Roche et al. 2012). However, some studies have reported a similar high prevalence of cymothoid isopods (e.g. $>40 \%$ in Leonardos \& Trilles 2003). These variations might be partly due to differences in the ecology, life history and life cycle, behavior, and population structure of the host fish, as well as to differences in cymothoid ecology and life history. However, most of these features are not known for the Japanese halfbeakM. parvostis parasitic system (and for many other host-cymothoid systems), pointing out the need for further studies on both host and parasite fundamental ecology to elucidate the mechanisms determining parasite prevalence.

\section{CONCLUSION}

This study demonstrated that the effect of Mothocya parvostis infection on Japanese halfbeak body condition varied among sampling sites. Such spatial variation in the effects of cymothoid infections might partly explain the inconsistencies found between previous studies, which were conducted mainly at a single study site (Bello et al. 1997, Leonardos \& Trilles 2003, Carrassón \& Cribb 2014). To better understand the effects of cymothoid infection, several study sites covering a variety of habitats, as well as host body size, should be included in future studies. This approach is even more important in a scenario where human activities increase the spatial heterogeneity of anthropogenic stresses. Our results also suggest that anthropogenic stresses might disrupt the hostparasite dynamics achieved through a long coevolutionary history.

Acknowledgements. We thank R. Tagashira, R. Dohi, A. Fujii, H. Matsuba, T. Oka, S. Tada, K. Itano, and J. Akahane for their support in field sampling and laboratory assistance. We also thank 2 anonymous reviewers for their critical comments and suggestions. This work was partly supported by the Mikimoto Fund for Marine Ecology and by the Showa Seitoku Memorial Foundation.

\section{LITERATURE CITED}

Adlard RD, Lester RJG (1995) The life cycle and biology of Anilocra pomacentri (Isopoda: Cymothoidae), an ectoparasitic isopod of the coral reef fish, Chromis nitida (Perciformes: Pomacentridae). Aust J Zool 43:271-281

Bello G, Vaglio A, Piscitelli G (1997) The reproductive cycle of Mothocya epimerica (Isopoda: Cymothoidae) a parasite of the sand smelt, Atherina boyeri (Osteichthyes: Atherinidae), in the Lesina Lagoon, Italy. J Nat Hist 31: 1055-1066

Binning SA, Roche DG, Layton C (2013) Ectoparasites increase swimming costs in a coral reef fish. Biol Lett 9: 20120927

Bottari T, Liguori M, Trilles JP, Giordano D, Romeo T, Perdichizzi F, Rinelli P (2013) Host-parasite relationship: occurrence and effect of Ceratothoa parallela (Otto, 1828) on Boops boops (L., 1758) in the Southern Tyrrhenian Sea. J Appl Ichthyol 29:896-900

Bruce NL (1986) Revision of the isopod crustacean genus Mothocya Costa, in Hope, 1851 (Cymothoidae: Flabellifera), parasitic on marine fishes. J Nat Hist 20:1089-1192

Brusca RC (1981) A monograph on the Isopoda Cymothoidae (Crustacea) of the eastern Pacific. Zool J Linn Soc 73:117-199

> Carrassón M, Cribb TH (2014) Benign effect of the fish parasitic isopod Ceratothoa cf. imbricata on Selenotoca multifasciata (Scatophagidae) from Australia. Dis Aquat Org 110:173-180

Colorni A, Trilles JP, Golani D (1997) Livoneca sp. (Flabellifera: Cymothoidae), an isopod parasite in the oral and branchial cavities of the Red Sea silverside Atherinomorus lacunosus (Perciformes, Atherinidae). Dis Aquat Org 31:65-71

Faul F, Erdfelder E, Lang AG, Buchner A (2007) G*Power 3: a flexible statistical power analysis program for the social, behavioral, and biomedical sciences. Behav Res Methods 39:175-191

Fogelman RM, Grutter AS (2008) Mancae of the parasitic cymothoid isopod, Anilocra apogonae: early life history, host-specificity, and effect on growth and survival of preferred young cardinal fishes. Coral Reefs 27:685-693

Fogelman RM, Kuris AM, Grutter AS (2009) Parasitic castration of a vertebrate: effect of the cymothoid isopod, Anilocra apogonae, on the five-lined cardinalfish, Cheilodipterus quinquelineatus. Int J Parasitol 39:577-583

> Gomiero LM, Souza UP, Braga FMS (2012) Condition factor of Astyanax intermedius Eigenmann, 1908 (Osteichthyes, Characidae) parasitised by Paracymothoa astyanaxi Lemos de Castro, 1955 (Crustacea, Cymothoidae) in the Grande River, Serra do Mar State Park- 
Santa Virgínia Unit, São Paulo, Brazil. Braz J Biol 72: 379-388

Halpern BS, Walbridge S, Selkoe KA, Kappel CV and others (2008) A global map of human impact on marine ecosystems. Science 319:948-952

Horton T, Okamura B (2003) Post-haemorrhagic anaemia in sea bass, Dicentrarchus labrax (L.), caused by blood feeding of Ceratothoa oestroides (Isopoda: Cymothoidae). J Fish Dis 26:401-406

$>$ Jensen KH, Little TJ, Skorping A, Ebert D (2006) Empirical support for optimal virulence in a castrating parasite. PLOS Biol 4:e197

Kuniyuki K, Koide T (1962) The ecological study of the Hemiramphus sajori (Temminck et Schlegel). Bull Naikai Reg Fish Res Lab 18:1-9 (in Japanese with English Abstract)

Leonardos I, Trilles JP (2003) Host-parasite relationships: occurrence and effect of the parasitic isopod Mothocya epimerica on sand smelt Atherina boyeri in the Mesolongi and Etolikon Lagoons (W. Greece). Dis Aquat Org 54:243-251

Martin MB, Bruce NL, Nowak BF (2015) Review of the buccal-attaching fish parasite genus Glossobius Schioedte \& Meinert, 1883 (Crustacea: Isopoda: Cymothoidae). Zootaxa 3973:337-350

Nakabo T (2002) Fishes of Japan with pictorial keys to the species, English edn. Tokai University Press, Tokyo

Östlund-Nilsson S, Curtis L, Nilsson GE, Grutter AS (2005) Parasitic isopod Anilocra apogonae, a drag for the cardinal fish Cheilodipterus quinquelineatus. Mar Ecol Prog Ser 287:209-216

Papapanagiotou EP, Trilles JP (2001) Cymothoid parasite Ceratothoa parallela inflicts great losses on cultured gilthead sea bream Sparus aurata in Greece. Dis Aquat Org 45:237-239

Poore GCB, Bruce NL (2012) Global diversity of marine isopods (except Asellota and crustacean symbionts). PLOS ONE 7:e43529

R Core Team (2014) R: a language and environment for statistical computing. R Foundation for Statistical Computing, Vienna

Roche DG, Strong LE, Binning SA (2012) Prevalence of the parasitic cymothoid isopod Anilocra nemipteri on its fish host at Lizard Island, Great Barrier Reef. Aust J Zool 60: 330-333

Editorial responsibility: Bernd Sures,

Essen, Germany
Sala-Bozano M, van Oosterhout C, Mariani S (2012) Impact of a mouth parasite in a marine fish differs between geographical areas. Biol J Linn Soc 105:842-852

Sandström A, Eriksson BK, Karås P, Isæus M, Schreiber H (2005) Boating and navigation activities influence the recruitment of fish in a Baltic Sea archipelago area. Ambio 34:125-130

Sarà G, Dean JM, D'Amato D, Buscaino G and others (2007) Effect of boat noise on the behaviour of bluefin tuna Thunnus thynnus in the Mediterranean Sea. Mar Ecol Prog Ser 331:243-253

> Sievers G, Lobos C, Inostroza R, Ernst S (1996) The effect of the isopod parasite Ceratothoa gaudichaudii on the body weight of farmed Salmo salar in southern Chile. Aquaculture 143:1-6

Smit NJ, Bruce NL, Hadfield KA (2014) Global diversity of fish parasitic isopod crustaceans of the family Cymothoidae. Int J Parasitol Parasites Wildl 3:188-197

Thatcher VE (2006) Amazon fish parasites. In: Adis J, Arias JR, Rueda-Delgado G, Wantzen KM (eds) Aquatic biodiversity in Latin America, Vol 1. Pensoft Publishers, Sofia, p 416-453

Tsuji T, Sadakata T (2000) Present status of the halfbeak fisheries in Japan. Bull Ishikawa Pref Fish Res Cent 2: 1-11 (in Japanese with English Abstract)

Wege GJ, Anderson RO (1978) Relative weight $\left(W_{\mathrm{r}}\right)$ : a new index of condition for largemouth bass. In: Novinger $G$, Dillard J (eds) New approaches to the management of small impoundments. Am Fish Soc North Cent Div Spec Publ 5, Bethesda, MD, p 79-91

Williams LB, Williams EH (1985) Brood pouch release of Anilocra chromis Williams \& Williams (Isopoda, Cymothoidae) a parasite of brown chromis, Chromis multilineatus (Guichenot) in the Caribbean. Crustaceana 49:92-95

Yamamoto M (2008) Spawning season of halfbeak Нyporhamphus sajori and seasonal change in their gonad somatic index and condition factor in the coastal waters of Kagawa Prefecture. Bull Kagawa Pref Fish Exp Stn 9: 1-4 (in Japanese with English Abstract)

- Yamauchi T, Nagasawa K (2012) Redescription of the fish parasite Nerocila japonica Schioedte \& Meinert, 1881 (Crustacea: Isopoda: Cymothoidae), with comments on previous records of $N$. acuminata in Japanese waters. Syst Parasitol 81:147-157

Submitted: February 8, 2016; Accepted: September 16, 2016 Proofs received from author(s): October 25, 2016 